\title{
BROWN-HEADED COWBIRD PARASITISM ON ENDANGERED SPECIES: RELATIONSHIPS WITH NEIGHBORING AVIAN SPECIES
}

\author{
Shannon L. Farrell1,3, Michael L. Morrison ${ }^{1}$, R. Neal Wilkins ${ }^{2}$, R. Douglas Slack ${ }^{1}$, \\ and Andrew J. Campomizzi ${ }^{1}$
}

\begin{abstract}
LLoss of reproductive productivity in hosts of the Brown-headed Cowbird (Molothrus ater), a nest parasite, may limit the success of conservation and recovery efforts that focus on restoring avian habitat. We investigated the relationships between parasitism frequency of 2 vireos-the endangered Black-capped Vireo (Vireo atricapillus) and the White-eyed Vireo (Vireo griseus) —and characteristics of the neighboring avian assemblage. Our objective was to identify assemblage characteristics that are useful for predicting parasitism frequency. We hypothesized that parasitism frequency of the vireos would decrease with increasing alternate host abundance and increase with increasing abundance of cowbirds. All Black-capped Vireo nests $(n=20)$ and $81 \%$ of White-eyed Vireo nests $(n=27)$ were parasitized. Parasitism frequency of White-eyed Vireos was positively correlated with the number of cowbirds detected $(r=0.84$, df $=$ $4, P=0.018)$. Parasitism frequency of White-eyed Vireos was negatively correlated with abundance of the Black-andwhite Warbler (Mniotilta varia; $r=0.891, \mathrm{df}=4, P=0.009$ ) but was not correlated with abundance of other cowbird hosts. The relationship between Black-and-white Warbler abundance and parasitism frequency may be due to chance, given the small sample size and narrow range of parasitism frequencies, but the relationship may also reflect an interaction (requiring further investigation) between parasitism and the vegetation characteristics associated with Black-andwhite Warblers. Our results imply that reducing cowbird abundance will reduce parasitism frequency of Black-capped Vireos. When the number of cowbirds in an area predicts parasitism, land managers would benefit from identifying a target cowbird abundance based on the levels of parasitism the host population can tolerate while still meeting productivity and population objectives for the species.
\end{abstract}

Key words: brood parasitism, Brown-headed Cowbird, Molothrus ater, Black-capped Vireo, Vireo atricapillus, Whiteeyed Vireo, endangered species, cowbird management.

RESUMEN.-La disminución de productividad debido al parasitismo por el tordo negro (Molothrus ater) podría limitar el éxito de los esfuerzos de conservación y recuperación de las aves que se centran en la restauración del hábitat. Investigamos la relación entre la frecuencia de parasitismo en el vireo gorrinegro (Vireo atricapilla), que está en peligro de extinción, y en otra especie de vireo, el vireo ojiblanco (Vireo griseus), así como su relación con las características de la población circunvecina de aves para identificar las características que sirven para predecir la frecuencia del parasitismo. Planteamos la hipótesis de que la frecuencia de parasitismo en los vireos disminuiría con el aumento de la abundancia de huéspedes alternativos y aumentaría al incrementarse la abundancia de tordos. Todos los nidos del vireo gorrinegro $(n=20)$ y el $81 \%$ de los nidos del vireo ojiblanco $(n=27)$ fueron parasitados. La frecuencia de parasitismo en los vireos ojiblancos estaba correlacionada positivamente con el número de tordos detectados $(r=0.84$, gdl $=4, P=$ 0.018). Estaba correlacionada negativamente con la abundancia $(r=0.891$, gdl $=4, P=0.009)$ del chipe trepador (Mniotilta varia), pero no estaba correlacionada con la abundancia de otros huéspedes de los tordos. La relación entre la abundancia de chipe trepador y la frecuencia da parasitismo podría ser aleatoria, dado lo pequeño de la muestra y la poca variación en las frecuencias de parasitismo, pero también podría reflejar una interacción entre el parasitismo y las características de la vegetación asociada con el chipe trepador que requiere más investigación. Nuestros resultados indican que la disminución de la abundancia de tordos reduce la frecuencia de parasitismo en el vireo gorrinegro. Cuando el número de tordos en una área predice el parasitismo, los administradores de recursos naturales podrían beneficiarse de la identificación de una abundancia meta del tordo, basada en los niveles de parasitismo que la población huésped pueda sostener y todavía alcanzar los objetivos de productividad y población de la especie.

Brood parasitism by the Brown-headed Cowbird (Molothrus ater) has been identified as a cause of nest failure for many avian species and has been implicated in the decline of several endangered species (Robinson et al. 1995,
Ortega 1998). Because cowbird management can be costly in time, money, and effort, determining the parasitism frequency for a species of concern and identifying the factors that can predict parasitism frequency in an area of

1Department of Wildlife and Fisheries Sciences, 210 Nagle Hall, 2258 TAMU, Texas A\&M University, College Station, TX 77843.
${ }^{2}$ Institute of Renewable Natural Resources, Texas A\&M University, College Station, TX 77843.

${ }^{3}$ E-mail: slfarrell@tamu.edu 
interest for a species of interest can assist managers in determining whether and where cowbird management should be implemented. Focusing cowbird management on sites where it is most likely to be successful in increasing nest success of a focal species may help increase the efficiency and efficacy of cowbird management.

Characteristics of the neighboring avian assemblage may affect the dynamics of cowbird parasitism in a habitat patch and can act as predictors of expected parasitism frequency. The density and proportion of cowbird egg hosts, acceptors, and rejecters in an area may influence cowbird breeding territory selection, distribution of cowbird eggs among nests, and parasitism frequency of a species of interest (Mason 1986a, 1986b, Burhans 1997). Some researchers have theorized that abundant hosts may act as an attractant that draws cowbirds to establish territories in an area, and some have found that cowbird abundance increases with increasing host density (Tewksbury at al. 1999). Other researchers have theorized that the presence of alternate hosts may dilute the effects of parasitism on a focal species (Smith et al. 2000). Previous research on the relationships between host abundance and cowbird abundance infers that these relationships translate to the same or a similar relationship between host abundance and actual parasitism frequency of a focal species. However, this relationship has not been studied directly in most cases; to our knowledge, Barber and Martin (1997) are the only researchers that have investigated this relationship directly and have found parasitism frequency of Black-capped Vireo (Vireo atricapillus) to be correlated with density of Northern Cardinals (Cardinalis cardinalis). Differences in potential host behavior, nesting phenology, nest site characteristics, and profitability to cowbirds suggest that additional factors can affect the relationship between host abundance and parasitism frequency.

The Black-capped Vireo is a federally endangered songbird, and primary threats are thought to be habitat loss and Brown-headed Cowbird parasitism (USFWS 1991). Human development, ranching, agriculture, and fire suppression have contributed to loss of breeding habitat, while cowbird parasitism has resulted in nest failure for the vireos (Graber 1961, Grzybowski 1995, Wilkins et al. 2006). In Texas, recovery efforts have focused on habitat restoration integrated into brush management regimes that use fire and selective cutting of juniper (Juniperus ashei; Wilkins et al. 2006). Intensive cowbird management is used across a small fraction of the Black-capped Vireo's range, but more widespread management may be necessary to recover this endangered species (Wilkins et al. 2006).

Recent estimates of Black-capped Vireo reproductive success have come mainly from areas with ongoing cowbird management (Kostecke et al. 2003, Noa et al. 2007) and are not applicable to most of central Texas where cowbird management is not implemented consistently. Previous researchers have reported cowbird parasitism on Black-capped Vireos as high as 90\% (Grzybowski et al. 1986, Weinberg et al. 1998, Kostecke et al. 2005; Weinberg et al. personal communication) prior to cowbird management (i.e., trapping). High parasitism can lower reproductive success and thereby limit the success of vegetation-focused habitat restoration efforts for Black-capped Vireos (Wilkins et al. 2006). Parasitism frequency of Blackcapped Vireos on private lands in the study region, where management varies from that on public land, has not been investigated previously. Thus, there is little information available to inform management of Black-capped Vireos on private land, including whether the parasitism frequency on these private lands warrants cowbird management and to what extent management may be needed.

Our goal was to determine the frequency of parasitism and investigate the relationship between parasitism frequency and characteristics of the neighboring avian assemblage. We focused on the Black-capped Vireo and the White-eyed Vireo (Vireo griseus) with the goal of providing data to inform management. We included the White-eyed Vireo because it is similar to the Black-capped Vireo in breeding behaviors and other natural history characteristics (Hopp et al. 1995), occupation of overlapping breeding territories, and parasitism frequencies (Ward and Smith 2000).

Previous surveys have found that cowbirds are common and widely distributed across the study region (Weinberg et al. 1998, Kostecke et al 2005; Weinberg et al. personal communication), so we did not expect to find a relationship between cowbird abundance and cumulative host abundance in an area as observed by Tewksbury et al. (1999). However, we expected 
that cumulative host abundance could dilute the effects of this widespread cowbird population on the vireos. Thus, we hypothesized that parasitism frequency of vireos would (1) decrease with increasing cumulative alternate cowbird host abundance, (2) decrease with increasing abundance of the most common alternate host, (3) increase with increasing abundance of Brown-headed Cowbirds or increase to a threshold level at which increasing cowbird abundance would not correlate with parasitism because all or most nests were parasitized, and (4) increase with increasing cumulative number of Brown-headed Cowbird detections. We used the cumulative number of cowbird detections across all survey visits during the breeding season as a measure of cumulative cowbird pressure on each study site and as a measure easily established by land managers without technical bird-sampling expertise.

\section{Methods}

\section{Study Area}

Our study area was the Leon River watershed, encompassing approximately 140,000 ha near the junction of the Lampasas Cut Plain and the northern Blackland Prairie ecoregions along the eastern portion of the Black-capped Vireo range (Griffith et al. 2004) in Coryell County, Texas. The majority of land in our study region is privately owned, excluding the Fort Hood Army Garrison. About 88\% of the private land in Coryell County is used for agriculture, including livestock ranching (U.S. Census Bureau 2005).

\section{Study Site Selection}

We identified 22 potential study sites based on prior Black-capped Vireo detections during point-count surveys conducted for the Leon River Restoration Project from 2003 to 2005 (Leon River Restoration Project, Texas A\&M University, unpublished data), and we identified presence of suitable habitat by examining digital imagery of the study region (Graber 1961, Barlow 1967, Benson and Benson 1990, Grzybowski et al. 1994, Grzybowski 1995) with ArcGIS $^{\mathrm{TM}}$ technology (ESRI 2005). We gained access to 12 of the 22 potential sites and conducted area searches for Black-capped Vireos from 15 March until 3 weeks after detection of the first male Black-capped Vireo, following the search methods of Ralph et al. (1991) and Dieni and Jones (2002). We played Black-capped Vireo song recordings during area searches to improve our chances of detecting the species. We detected Black-capped Vireos at 6 of the 12 potential sites; we used all 6 sites with Blackcapped Vireo detections as study sites. We detected White-eyed Vireos at the 6 sites in areas overlapping those occupied by Blackcapped Vireos. Study sites ranged from 20 to 50 ha.

\section{Nest Location and Monitoring}

We located and monitored nests from 20 March to 20 July 2006. We mapped territories (Ralph et al. 1991) for the first 3-4 weeks after vireo arrival. We monitored each territory 2 times per week, between 15 minutes before and approximately 6 hours after local sunrise. We used behavioral observations and systematic search techniques (Martin and Geupel 1993) to locate nests. We checked nests every 1-4 days and recorded the contents, including host and cowbird eggs and young. We recorded the outcome of all nests at completion and recorded confirmaatory descriptive observations, such as signs of predation, broken eggshells, or adult birds carrying food.

\section{Identifying Avian Assemblage}

We used 100-m-radius circular-plot point counts (Rosenstock et al. 2002) to determine bird species composition and abundance. The 4-7 point-count stations within each study site were systematically spaced $200-300 \mathrm{~m}$ apart to provide adequate coverage. We alternated among several observers to minimize observer bias and varied the order in which points on a study site were surveyed to avoid detection bias due to time of day. To account for imperfect detection, we conducted 3 surveys at each point-count station and then averaged the number of dectections at each station before analysis. We conducted surveys between 15 minutes before and 3 hours after local sunrise from 1 April to 1 June 2006. Surveys consisted of 6 minutes of passive listening, during which we recorded all birds detected within the 100-m radius, detection type (song, call, or visual), gender (male, female, juvenile, or unknown), and distance $(0-50 \mathrm{~m}$ or $50-100 \mathrm{~m})$ for each individual. In the data set for analysis, we included only species for which there have been confirmed nesting records in Coryell County or adjacent 
counties (Texas A\&M University System 2001). To account for imperfect detection in our pointcount surveys, we used PRESENCE (USGS 2006) to calculate detection probabilities for all species included in our analysis (MacKenzie 2005, Mackenzie et al. 2005). We found that detection probabilities for 3 visits were adequate to provide a probability of detection approaching 1 over all survey visits (Farrell 2007).

\section{Calculating Parasitism Frequency}

For analysis, we used nests that had reached at least laying stage and whose contents we observed at each nest check. We counted nests as parasitized if they had received a cowbird egg during laying or within the first 5 days of incubation. We calculated frequency of parasitism as the proportion of parasitized nests among total nests monitored at each study site. We calculated parasitism frequency for the Black-capped Vireo and the White-eyed Vireo; we then combined parasitism frequency for both species. We used chi-square analysis to test for differences in parasitism frequency among study sites (Daniel 1990: 181-198).

\section{Avian Assemblage and Parasitism Frequency}

Because we detected only a few individuals for most species, we were not able to use distance-based detection probabilities (Ellingson and Lukacs 2003), as these models are not useful for rare or even moderately abundant species (Queheillalt et al. 2002, Purcell et al. 2005). We assumed that the probability of detecting each species was consistent across the 6 study sites; high detection probabilities (MacKenzie 2005, Mackenzie et al. 2005) and homogeneity in vegetation characteristics among sites suggested this assumption was reasonable. We calculated an index of cumulative bird abundance, cowbird host abundance, and individual species abundance using data within the 100-m point-count radius. We used data within the 100-m radius for all analyses because the low number of birds detected within the 50-m radius provided limited information for analysis and the relationship between abundance at the 50-m and 100-m radii was consistent among study sites. We calculated abundance as the mean number of birds detected per count station averaged across the 3 survey visits. We omitted from analysis any species for which we had fewer than 2 detections over the course of all 3 survey visits across all 30 point-count stations (i.e., 90 survey occasions).

We counted the number of species detected at each site and used Sorensen's similarity index to examine similarity among sites (Amezaga et al. 2004). We estimated the proportion of birds of a given species among all birds detected for each study site to represent one aspect of the species composition. We used a Kruskal-Wallis test to identify differences in assemblage characteristics among study sites (Zar 1984:176-179; Daniel 1990:226-231) for cumulative bird abundance, cowbird host abundance, and abundance of each species detected. Cumulative number of Brown-headed Cowbird detections was summed for all survey visits and was intended to function as a measure of the cumulative cowbird pressure on each study site over the breeding season and as a measure that can be easily established by managers without requiring additional calculations or statistical procedures. We used scatter plots to preliminarily explore data relationships. We conducted one-tailed Pearson correlation tests (Zar 1984: 318-320) to test our hypotheses that parasitism frequency decreased with (1) cumulative alternate host abundance and (2) abundance of each of the most common alternate hosts, and that parasitism frequency increased with (3) abundance of Brown-headed Cowbirds and (4) cumulative number of Brown-headed Cowbird detections on each study site. We also investigated relationships between mean number of cowbird eggs per nest and the independent variables listed in 1-4 above.

\section{Results}

\section{Parasitism Frequency}

We monitored 20 Black-capped Vireo nests from 15 pairs, and 27 White-eyed Vireo nests from 38 pairs. All Black-capped Vireo nests and $81 \%$ of White-eyed Vireo nests were parasitized. We observed 17 of the 42 parasitized vireo nests that contained 2 cowbird eggs or young and 3 nests that contained 3-4 cowbird eggs or young. Parasitism frequency did not differ significantly among study sites $\left(\chi^{2}=4.30, \mathrm{df}=\right.$ $5, P=0.51)$. Combined parasitism frequency of the 2 vireo species ranged from 0.71 to $1(\bar{x}$ $=0.89, \mathrm{SE}=0.04$ ) across the 6 study sites. Parasitism frequency was similar among study sites for both species with the exception of 
TABLE 1.-Mean abundance, calculated as birds per point, and standard error of the most common species detected during point-count surveys in 2006 on private lands in Coryell and Hamilton counties, Texas. An asterisk indicates species that are known to be common or frequent cowbird host species.

\begin{tabular}{llcc}
\hline Common name & Scientific name & $\begin{array}{c}\text { Mean } \\
\text { abundance }\end{array}$ & $\begin{array}{c}\text { Standard } \\
\text { error }\end{array}$ \\
\hline Northern Cardinal* $^{*}$ & Cardinalis cardinalis & 2.20 & 0.12 \\
White-eyed Vireo* & Vireo griseus & 1.19 & 0.30 \\
Brown-headed Cowbird & Molothrus ater & 0.91 & 0.10 \\
Blue-gray Gnatcatcher* & Polioptila caerulea & 0.84 & 0.13 \\
Painted Bunting* & Passerina ciris & 0.78 & 0.16 \\
Carolina Chickadee & Poecile carolinensis & 0.58 & 0.12 \\
Bewick's Wren & Thryomanes bewickii & 0.45 & 0.10 \\
Black-crested Titmouse & Baeolophus atricristatus & 0.42 & 0.06 \\
Mourning Dove & Zenaida macroura & 0.36 & 0.08 \\
Carolina Wren & Thryothorus ludovicianus & 0.34 & 0.05 \\
American Crow & Corvus brachyrhynchos & 0.25 & 0.04 \\
Golden-cheeked Warbler* & Dendroica chrysoparia & 0.22 & 0.07 \\
Black-and-white Warbler* & Mniotilta varia & 0.22 & 0.05 \\
Black-capped Vireo* & Vireo atricapilla & 0.17 & 0.07 \\
Yellow-billed Cuckoo & Coccyzus americanus & 0.14 & 0.03 \\
Field Sparrow* & Spizella pusilla & 0.12 & 0.06 \\
Rufous-crowned Sparrow* & Aimophila ruficeps & 0.11 & 0.04 \\
Black-chinned Hummingbird & Archilocus alexandri & 0.11 & 0.06 \\
Lark Sparrow* & Chondestes grammacus & 0.10 & 0.05 \\
\hline
\end{tabular}

one site. We found 3 White-eyed Vireo nests on site 4 , with only 1 parasitized. With the exception of site 4 , observed parasitism frequency of White-eyed Vireo nests was lower than that of Black-capped Vireo nests by $0 \%-25 \%(\bar{x}=11 \%, \mathrm{SE}=5 \%)$. The earliest clutch-initiation date we observed was 6 April for White-eyed Vireos and 14 April for Blackcapped Vireos. The last active Black-capped Vireo nest failed on 14 June. No Blackcapped Vireo nests were initiated after 5 June, but 5 White-eyed Vireo nests were initiated after 5 June, while the last observed Whiteeyed Vireo nest was initiated on 2 July. Of the 5 White-eyed Vireo nests initiated after 5 June, only one was parasitized. We used White-eyed Vireo parasitism frequency for further analyses comparing parasitism frequency to assemblage characteristics, because Black-capped Vireo parasitism frequency was $100 \%$.

\section{Avian Assemblage}

We detected 33 species of birds known to breed in the study region (Table 1). The number of species detected per site ranged from 17 to $25(\bar{x}=21, \mathrm{SE}=3)$. Sorensen's similarity index ranged from 0.76 to $0.95(\bar{x}=0.82$, $\mathrm{SE}=0.01$ ), suggesting a high level of similarity in species present among the sampling units. Similarity index values did not differ significantly among sites $(\bar{x}=8.05, \mathrm{df}=5, P=0.15)$.
Cumulative bird abundance ranged from 7.9 to 11.3 birds per point $(\bar{x}=9.9, \mathrm{SE}=0.5)$. We did not find significant differences in cumulative bird abundance among study sites $(H=4.39$, $\mathrm{df}=5, P=0.49)$ or in any pairwise comparison between study sites.

We detected $9.0(\mathrm{SE}=0.4)$ cowbird hosts per 100-m-radius point count. We did not find significant differences in abundance of known cowbird hosts among study sites $(H=4.37$, $\mathrm{df}=5, P=0.50)$ or for any pairwise comparison between sites. Northern Cardinals were the most abundant species on all sites with $1.9-2.7$ birds per point $(\bar{x}=2.2, \mathrm{SE}=0.1)$. White-eyed Vireos were the second most abundant species with $0.3-2.5$ birds per point $(\bar{x}=1.19, \mathrm{SE}=0.3)$, followed by Brownheaded Cowbirds with 0.5-1.3 birds per point $(\bar{x}=0.91, \mathrm{SE}=0.1)$.

\section{Parasitism Frequency and Avian Assemblage Relationships}

We did not find a statistically significant relationship between parasitism frequency and cumulative host abundance (Pearson's $r=0.39$, $\mathrm{df}=4, P=0.45)$. Cowbird host species with a mean abundance of $>0.10$ birds per point were included in further analyses (Table 1). We did not find significant correlations between observed parasitism frequency and abundance of alternate host species for 7 of the 8 species we tested, but we did find that parasitism frequency 


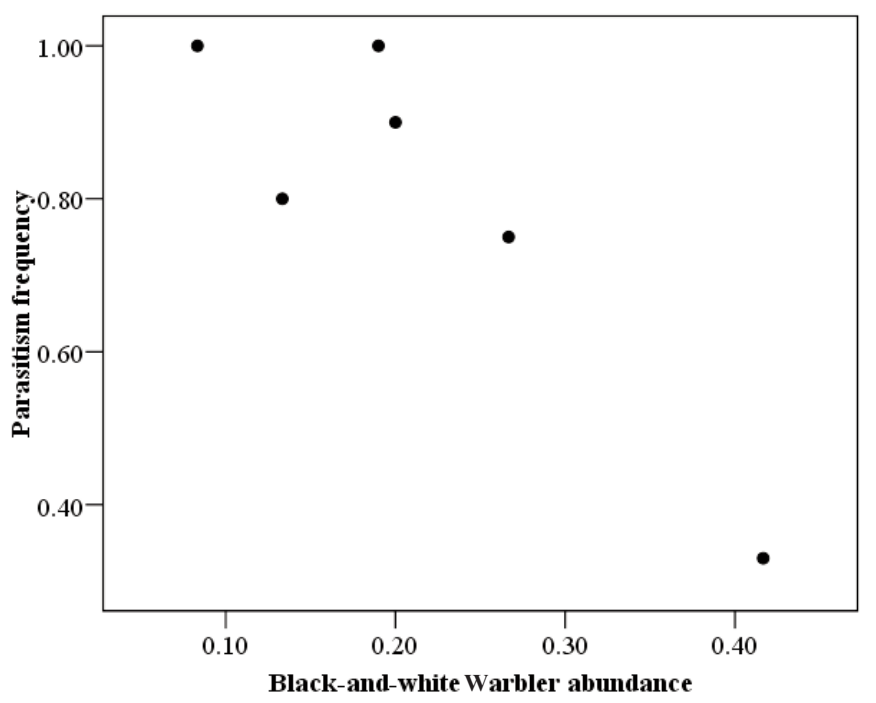

Fig. 1. Brown-headed Cowbird parasitism frequency on White-eyed Vireo nests plotted against Black-and-white Warbler abundance on 6 study sites in Coryell County, Texas, in 2006.

was lower on sites with higher abundance of Black-and-white Warblers $(r=0.891, \mathrm{df}=4$, $P=0.009$; Fig. 1). We found a positive relationship between parasitism frequency and Brown-headed Cowbird abundance $(r=0.76$, $\mathrm{df}=4, P=0.04)$. Cumulative number of cowbird detections on each site, not independent from cowbird abundance but included here for its practical applications, was positively correlated with parasitism frequency $(r=$ $0.84, \mathrm{df}=4, P=0.018)$. We did not find significant relationships between mean number of cowbird eggs per nest and cumulative host abundance or abundance of any of the cowbird host species we tested. Parasitism frequency of the White-eyed Vireo ranged from 0.33 to 1 ; total number of cowbirds detected at each site ranged from 6 to 19 .

\section{Discussion}

Parasitism frequencies of the Black-capped and White-eyed Vireos were high enough to substantially impact productivity (Porneluzi and Faaborg 1999, Powell et al. 1999). We found a relationship between number of cowbirds detected and parasitism frequency; thus, number of cowbird detections may be a useful predictor of expected parasitism frequency. We did not find that parasitism frequency was correlated with host abundance; thus, our results do not support our hypothesis that greater host abun- dance may dilute parasitism of the vireo. Contrary to Barber and Martin (1997), we did not find a correlation between parasitism frequency and abundance of Northern Cardinals.

Parasitism frequency was negatively correlated with abundance of Black-and-White Warblers. Though the result was not statistically significant (Bonferroni correction for multiple comparisons, $\alpha=0.006)$, this result may be biologically significant $(r=0.891, \mathrm{df}=4, P=$ $0.009)$ given our small sample size. Black-andwhite Warblers are known cowbird hosts (Hahn and Hatfield 1995); however, we did not find decreasing parasitism frequency with abundance of other, more numerous cowbird hosts. Thus, we do not think the relationship was due to Black-and-white Warblers diluting parasitism on the vireos. This apparent relationship may be attributable to chance, given the small sample size and narrow range of parasitism frequencies. However, the relationship may be indirect because of differences in the vegetation surrounding Black-capped Vireo habitat across study sites that may affect parasitism frequency on vireos. Black-and-white Warblers are associated with mature, closed-canopy woodland (Kricher 1995). Many researchers have investigated whether cowbird parasitism decreases, increases, or remains unchanged as habitat becomes more forested (e.g., Lowther and Johnston 1977, Hahn and 
Hatfield 1995, Burhans 1997, Goguen and Mathews 2000, Jensen and Cully 2005). Findings, however, are not consistent, suggesting that the relationship between vegetation and parasitism frequency may vary regionally or with cowbird density. Further investigation across a wider range of parasitism frequencies, host densities, and vegetation characteristics is necessary to investigate relationships among these multiple factors, and to determine if the mechanisms driving these relationships are related to host abundances, nesting behavior, vegetation characteristics, or other factors. However, for purposes of informing cowbird management, knowledge of the mechanism may not be necessary; it may be sufficient to establish that parasitism of vireos is lower at sites with greater abundance of Black-and-white Warblers.

Similarity in parasitism frequency among study sites may have been due to similar vegetation and avian assemblage characteristics. The reason for the $20 \%$ difference in parasitism frequency between White-eyed and Black-capped Vireos is not clear. Response to parasitism does not appear to vary between the 2 species. Neither species is known to frequently abandon parasitized nests or to eject or bury cowbird eggs, and we did not observe any rejecting behavior. Nest locations are often indistinguishable between the 2 vireo species, and nestling diets appear to be similar (Grzybowski 1995, Hopp et al. 1995). Differences in adult host behavior at or near the nest may be a possible explanation, as previous observational studies have concluded that female cowbirds may locate nests to parasitize by watching adults build nests (Hann 1937, 1941). Further studies that quantify behavior at the parasitized and unparasitized nests of these 2 species may help explain the differences we observed.

If our sample was representative of Blackcapped Vireos breeding elsewhere in the region on sites without cowbird management, our results indicate that the Black-capped Vireo population in our study region experienced high parasitism frequencies and consequently may have produced few, if any, young in 2006. These results further suggest that recovery efforts focused on vegetation restoration alone may have limited success due to loss of Black-capped Vireo productivity from cowbird parasitism.

The relationship between parasitism frequency of the vireos and cowbird numbers suggests that cowbird numbers can be a reasonable predictor of expected parasitism frequency, and this predictive power can inform management decisions. Sampling to count cowbirds requires minimal training, and the resulting information can be used to determine expected parasitism frequencies in areas of interest. Land managers can choose to implement cowbird management in select areas depending on management objectives. Sites with relatively low cowbird abundance might show successful increases in productivity faster under cowbird management. Sites with high expected parasitism might require longer or more intensive cowbird management before results are apparent, as cowbird abundance is reduced to a level that enables a significant increase in host productivity. Land managers can use information on expected parasitism frequency to choose implementation strategies that meet specific cowbird management objectives. The high frequency of parasitism and cowbird abundance observed on our study sites suggests that active cowbird management should be considered for the study region and would likely to be an important tool for increasing the nest success of Black-capped Vireos and for implementing broader restoration efforts.

\section{ACKNOWLEDGMENTS}

We thank the Department of Defense, Office of the Secretary of Defense, and the Readiness Environmental Protection Initiative for financial support. Additional support was provided by the Texas A\&M Institute of Renewable Natural Resources, the Central Texas Cattlemen's Association, the USDA Natural Resources Conservation Service, the National Fish and Wildlife Foundation, and the Texas Parks and Wildlife Department. We thank landowners and managers for land access. We thank Brian Hays, Steve Manning, Don Petty, Laura Law, Amy Snelgrove, and Jerrod Butcher for logistical and technical support. We thank field technicians Ardath Lawson, Chris Lituma, and Claire Curry for data collection.

\section{Literature Cited}

Amezaga, I., S. Mendarte, I. Albizu, G. Besga, C. GarBISU, AND M. ONAINDIA. 2004. Grazing intensity, aspect, and slope effects on limestone grassland 
structure. Rangeland Ecology and Management $57: 606-612$.

Barber, D.R., AND T.E. Martin. 1997. Influence of alternate host densities on Brown-headed Cowbird parasitism rates in Black-capped Vireos. Condor 99:595-604

BARLOW, J.C. 1967. Nesting of the Black-capped Vireo in the Chisos Mountains, Texas. Condor 69:605-608.

Benson, J.C., AND K.L.P. BENSON. 1990. Estimated size of Black-capped Vireo population in northern Coahuila, Mexico. Condor 69:605-608.

BurHANS, D.E. 1997. Habitat and microhabitat features associated with cowbird parasitism in two forest edge cowbird hosts. Condor 99:866-872.

DANIEL, W.W. 1990. Applied nonparametric statistics. 2nd edition. PWS-Kent, Boston, MA.

Dieni, J.S., AND S.L. JonEs. 2002. A field test of the area search method for measuring breeding bird populations. Journal of Field Ornithology 73:253-257.

ELLINGSON, A.R., AND P.M. LUKACS. 2003. Improving methods for regional landbird monitoring: a reply to Hutto and Young. Wildlife Society Bulletin 31:896-902.

[ESRI] Environmental Systems Research Institute. 2005. ArcMap 9.1. Redlands, CA.

FARRELL, S.L. 2007. Brown-headed Cowbird parasitism on endangered species: relationships with neighboring avian species. Master's thesis, Texas A\&M University, College Station, TX

Goguen, C.B., AND N.E. Mathews. 2000. Local gradients of cowbird abundance and parasitism relative to livestock grazing in a western landscape. Conservation Biology 14:1862-1869.

Graber, J.W. 1961. Distribution, habitat requirements, and life history of the Black-capped Vireo (Vireo atricapilla). Ecological Monographs 31:313-336.

Griffith, G.E., S.A. Bryce, J.M. Omernik, J.A. ComStock, A.C. Rogers, B. Harrison, S.L. Hatch, AND D. BEZANSON. 2004. Ecoregions of Texas [color poster with map, descriptive text, and photographs; map scale 1:2,500,000]. U.S. Geological Survey, Reston, VA.

Grzybowsкi, J.A. 1995. Black-capped Vireo (Vireo atricapillus). Account 181 in A. Poole and F. Gill, editors, The birds of North America. Academy of Natural Sciences, Philadelphia, PA, and American Ornithologists' Union, Washington, DC.

Grzybowski, J.A., R.B. Clapp, and J.T. Marshall. 1986. History and current population status of the Blackcapped Vireo in Oklahoma. American Birds 40: $1151-1161$

Grzybowski, J.A., D.J. TaZiK, AND G.D. Schnell. 1994. Regional analysis of Black-capped Vireo breeding habitats. Condor 96:512-544.

Hahn, D.C., and J.S. Hatfield. 1995. Parasitism at the landscape scale: cowbirds prefer forests. Conservation Biology 9:1415-1424.

HanN, H.W. 1937. Life history of the Oven-bird in southern Michigan. Wilson Bulletin 49:146-235.

. 1941. The cowbird at the nest. Wilson Bulletin 53:211-221.

Hopp, S.L., A. KirbY, AND C.A. Boone. 1995. White-eyed Vireo (Vireo griseus). Account 168 in A. Poole and F. Gill, editors, The birds of North America. Academy of Natural Sciences, Philadelphia, PA, and American Ornithologists' Union, Washington, DC.

Jensen, W.E., AND J.FJ. Cully. 2005. Density-dependent habitat selection by Brown-headed Cowbirds
(Molothrus ater) in tallgrass prairie. Oecologia 142: 136-149.

Kostecke, R.M., J.A. Koloszar, and D.C. Dearborn. 2003. Effect of a reduction in cattle stocking rate on Brownheaded Cowbird activity. Wildlife Society Bulletin 31:1083-1091.

Kostecke, R.M., S.G. Summers, G.H. EcKrich, and D.A. CipRICH. 2005. Effects of Brown-headed Cowbird (Molothrus ater) removal on Black-capped Vireo nest success and population growth at Fort Hood, Texas. Ornithological Monographs 57:2837.

KRICHER, J.C. 1995. Black-and-white Warbler (Mniotilta varia). Account 158 in A. Poole and F. Gill, editors, The birds of North America, Academy of Natural Sciences, PA, Pennsylvania, and American Ornithologists' Union, Washington, DC

LOWTHER, P.E., AND R.F. Johnston. 1977. Influences of habitat on cowbird host selection. Kansas Ornithological Society Bulletin 28:36-40.

MacKenZie, D.I. 2005. What are the issues with 'presence/ absence' data for wildlife managers? Journal of Wildlife Management 69:849-860.

MacKenzie, D.I., J.D. Nichols, J.A. Royle, K.H. Pollock, J.E. Hines, AND L.L. BAILEY. 2005. Occupancy estimation and modeling: inferring patterns and dynamics of species occurrence. Elsevier, San Diego, CA.

Martin, T.E., and G.R. GeupeL. 1993. Nest-monitoring plots: methods for locating nests and monitoring success. Journal of Field Ornithology 64:507-519.

Mason, P. 1986a. Brood parasitism in a host generalist, the Shiny Cowbird: I. The quality of different species as hosts. Auk 103:52-60.

1986b. Brood parasitism in a host generalist, the Shiny Cowbird: II. Host selection. Auk 103:61-69.

Noa, L.A., D.H. HirTh, T.M. Donovan, and D. Cimprich. 2007. Demographic differences of Black-capped Vireos in 2 habitat types in central Texas. Journal of Wildlife Management 71:1042-1049.

Ortega, C.P. 1998. Cowbirds and other brood parasites. University of Arizona, Tucson, AZ.

Porneluzi, P.A., AND J. FaAborg. 1999. Season-long fecundity, survival, and viability of ovenbirds in fragmented and unfragmented landscapes. Conservation Biology 13:1151-1161.

Powell, L.A., M.J. Conroy, D.G. Krementz, and J.D. LANG. 1999. A model to predict breeding-season productivity for multibrooded songbirds. Auk 116:10011008.

Purcell, K.L., S.R. Mori, And M.K. Chase. 2005. Design constraints for examining trends in avian abundance using point counts: examples from oak woodlands. Condor 107:305-320.

Queheillalt, D.M., J.W. Cain III, D.E. Taylor, M.L. Morrison, S.L. Hoover, N. Tuatoo-Bartley, L. Rugge, K. Christopherson, M.D. Hulst, M.R. HarRIS, AND H.L. KeOUgh. 2002. The exclusion of rare species from community-level analyses. Wildlife Society Bulletin 30:756-759.

Ralph, C.J., G.R. Geupel, P. Pyle, T.E. Martin, and D.F. DESANTE. 1991. Handbook of field methods for monitoring landbirds. General Technical Report PSW144, U.S. Department of Agriculture Forest Service.

Robinson, S.K., S.I. Rothstein, M.C. BRitTinghaM, L.J. Petit, and J.A. Grzybowski. 1995. Ecology of cowbirds and their impact on host populations. Pages 428-460 in T.E. Martin and D.M. Finch, editors, Ecology and management of neotropical 
migratory birds. Oxford University Press, New York, NY.

Rosenstock, S.S., D.R. Anderson, K.M. Giesen, T. LeukERING, AND M.F. CARTER. 2002. Landbird counting techniques: current practices and an alternative. Auk 119:46-53.

SMith, J.N.M., T.L. CoOK, S.I. RothsteIN, S.K. Robinson, AND S.G. SEALY, EDITORS. 2000. Ecology and management of cowbirds and their hosts. University of Texas, Austin, TX.

Tewksbury, J.J., T.E. Martin, S.J. Hejl, T.S. Redman, AND FJ. WHEELER. 1999. Cowbirds in a western valley: effects of landscape structure, vegetation, and host density. Pages 23-33 in M.L. Morrison, L.S. Hall, S.K. Robinson, S.I. Rothstein, D.C. Hahn, and T.D. Rich, editors, Research and management of the Brown-headed Cowbird in western landscapes. Cooper Ornithological Society, Lawrence, KS.

Texas A\&M University System. 2001. The Texas breeding bird atlas. [Cited 25 August 2006]. Available from: http://txtbba.tamu.edu/index.html

U.S. Census Bureau. 2005. Coryell County, Texas. [Cited 1 September 2006]. Available from: http://quickfacts .census.gov/qfd/states/48/48099lk.html

[USFWS] U.S. FiSH AND WILDLIFE SERVICE. 1991. Blackcapped Vireo recovery plan. U.S. Fish and Wildlife
Service Office of Endangered Species, Albuquerque, $\mathrm{NM}$.

[USGS] U.S. Geological Survey. 2006. PRESENCE 2.0. USGS Patuxent Wildlife Research Center, Laurel, MD. Available from: http://www.mbr-pwrc.usgs.gov/ software/presence.html

WARD, D., AND J.N.M. SMITH. 2000. Brown-headed Cowbird parasitism results in a sink population in Warbling Vireos. Auk 117:337-344.

WeinberG, H.J., T.J. Hayden, AND J.D. CoRnelius. 1998. Local and installation-wide Black-capped Vireo dynamics on the Fort Hood, Texas Military Reservation. Technical Report 98/54, U.S. Army Construction Engineering Research Laboratories [USACERL], Champaign, IL.

WiLkins, N., R.A. Powell, A.A.T. ConkEy, AND A.G. SNELGROVE. 2006. Population status and threat analysis for the Black-capped Vireo. U.S. Fish and Wildlife Service, Region 2, Albuquerque, NM.

ZAR, J.H. 1984. Biostatistical analysis. 2nd edition. Prentice-Hall, Englewood Cliffs, NJ.

Received 9 February 2009 Accepted 24 June 2010 